\title{
REPORT ON FIELD WORK ALONG THE NORTH COAST OF DISKO, 1971
}

\author{
Asger Ken Pedersen
}

\section{Introduction}

During the summer field work was carried out along the north coast of Disko. This work was a continuation of investigations in 1968 (see Pedersen, 1969, 1970). The purpose of the work was to study the section across the Tertiary volcanic zone exposed along the north coast of Disko and to sample the volcanic rocks for petrological investigation. A zone about $40 \mathrm{~km}$ long, from the Kûgánguaq valley to just north-west of Qutdligssat, was mapped, representing a volcanic pile at least $2.3 \mathrm{~km}$ thick (see fig. 7).

\section{Gross structures}

An inlier of gneiss extends through Disko from Godhavn to Stordalen. Although not exposed further north it may continue at depth to the Vaigat around the outer part of the Kûgánguaq valley. West of the ridge a complicated fault pattern is found. East of the ridge the Tertiary rocks are only slightly faulted (Henderson, in press).

Cretaceous non-marine sandstones and black shales outcrop a few kilometres east of the Kûgánguaq valley and continue towards the east. Just east of Kugánguaq they strike NW-SE to N-S and dip 10-20 NE to E. Further east the dip is less.

Prior to the volcanic eruptions the Cretaceous surface was eroded. A considerable small scale topography is displayed by the relatively few exposures of the old surface. The land surface sloped from south-east towards north-west. A few metres of sediments resting discordantly on the Cretaceous sediments were observed in a small depression in this old landscape, later buried by volcanic rocks. Because of the initial slope in the land surface there is a progressive onlap of the volcanic rocks on to the old surface from north-west to south-east.

During the volcanic period there was a gradual sinking of the eastern part of 


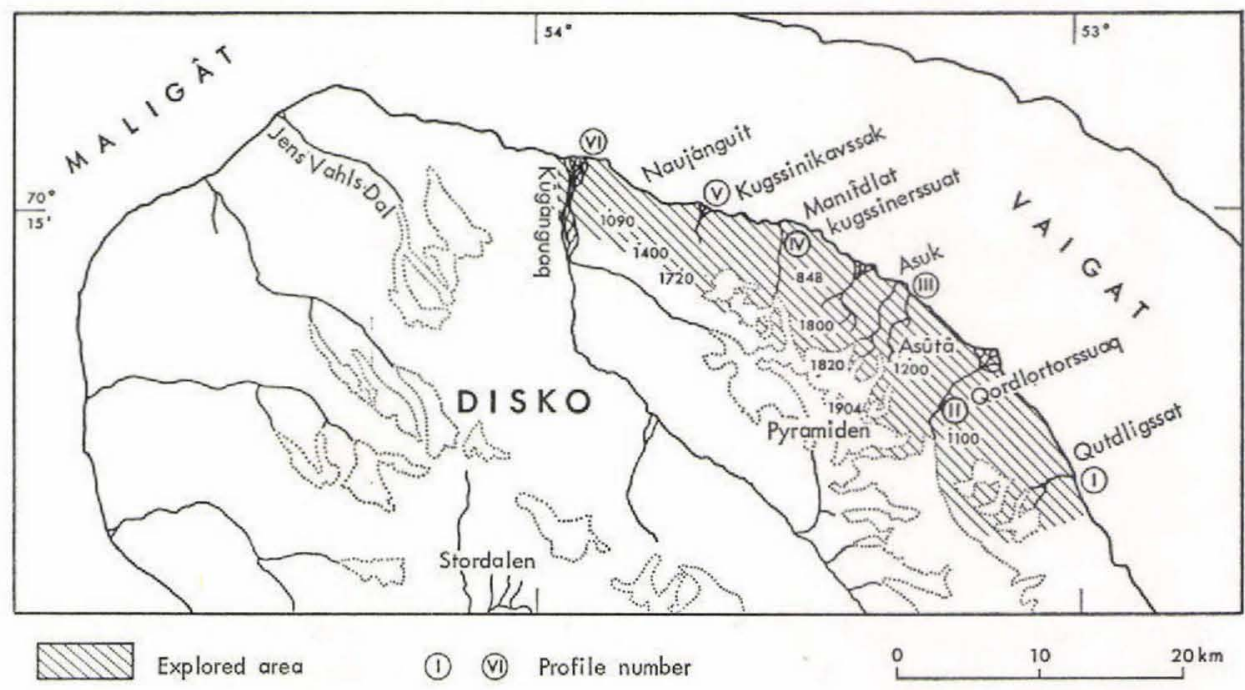

Fig. 7. Map of northern Disko showing the area explored and the locations of profiles measured.

the plateau relative to a zone from outer Kûgánguaq to the central part of Stordalen, i. e. the supposed continuation of the gneiss ridge. The dips range from subhorizontal to a few degrees towards the south and south-east. The surface was near sea level, and the volcanic units can therefore often be traced from subaerial lava facies to subaqueous breccia facies from north-west to south-east. The relative positions of sea level can be seen at the upper surface of a major pillow breccia horizon found in the sequence.

The volcanic sequence comprises a lower lava formation of predominantly olivine basalts and an upper lava formation of predominantly feldspar-phyric basalts.

A detailed volcanic stratigraphy has been worked out, combining variation in chemical and mineralogical composition and in lithology. In the following pages a short description is given of a number of units occurring in the otherwise monotonous sequence of olivine basalts, picrite basalts and feldspar-phyric basalts. Fig. 8 shows a number of schematic profiles from the section. (The stratigraphic nomenclature used for the volcanic rocks in this account is informal.)

\section{Lower lava formation}

The lower lava formation attains a thickness of more than $1.5 \mathrm{~km}$ in the western part of the section, but in the easternmost part does not exceed $500 \mathrm{~m}$. 


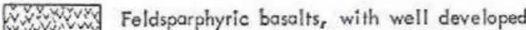

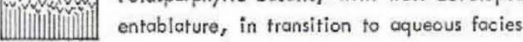

\section{Mildly alkaline basalts}

\section{[Tा TIITI] Aphyric or olivine-poor basalts,} lower lava formation

\section{Olivine basalts and picrite basalts}

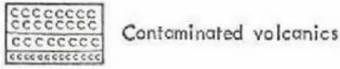

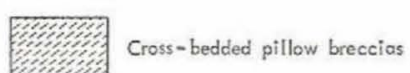

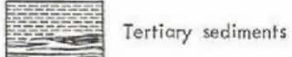

\section{No exposures}

Cretaceous sediments

1-9 Units described in text

Profile III is partly reconstructed from large landslipped blocks
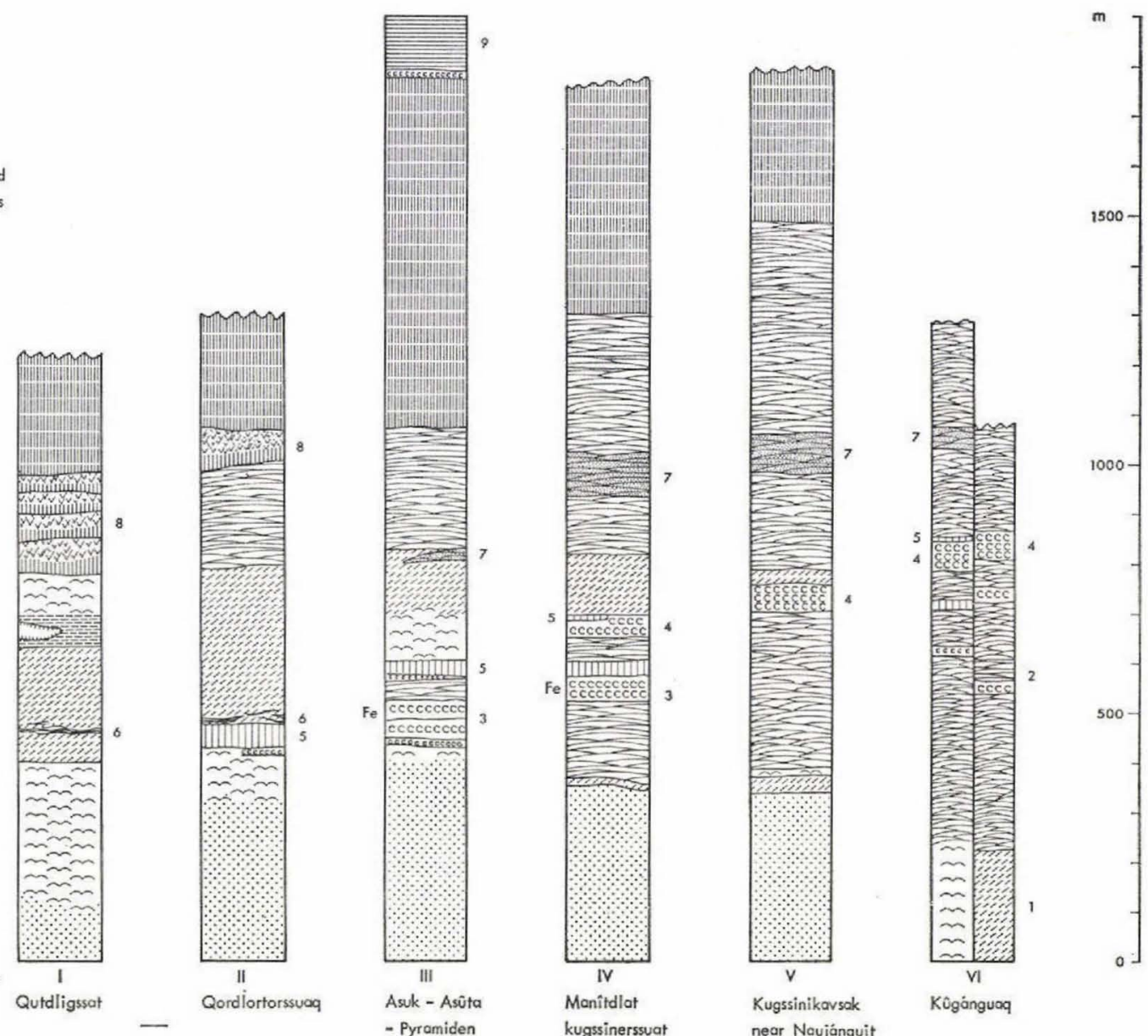

Fig. 8. Schematic profiles along the north coast of Disko. The localities are shown on fig. 7. 
Unit 1 comprises at least $230 \mathrm{~m}$ of cross-bedded olivine basaltic pillow breccias deposited in a depression at least $300 \mathrm{~m}$ deep eroded in Cretaceous sediments. Neither the base nor the western extension is exposed above sea level. Unit 1 is only found around the outer part of the Kungánguaq valley. The breccias show a provenance of magma from the north.

The breccias are covered by brownish-weathering, olivine basaltic lavas, many of which pass into near-shore pillow lavas and breccias of near-shore origin within a few kilometres to the south-east. The lavas pass upwards into greyish-weathering picritic flows.

Unit 2 is a sequence whose lower part consists of light brownish weathering, orthopyroxene-bearing lavas, contaminated by sandstones and shales, and whose upper part consists of dark brown weathering olivine basalts. A few picritic flows can separate the lower and upper part of the unit. From a few kilometres east of the Kûgánguaq valley, unit 2 can be followed across the valley towards the west.

Unit 3 is a sequence up to $100 \mathrm{~m}$ thick of contaminated often orthopyroxenerich lavas, including telluric iron bearing flows. It can be followed for $20 \mathrm{~km}$ along the coast from Kugssinikavsak at Naujanguit to south-east of the mountain Asûtâ. In the western part of the section only subaerial lavas occur. In the eastern part there are also pillow lavas and breccias, which form here the base of the volcanic pile. At the classical locality of Asuk (Steenstrup 1882), where unit 3 forms part of a large downthrown block, a telluric iron bearing composite lava of early, slightly contaminated basalt and later, more contaminated siliceous rock has been investigated.

Unit 4 is a sequence up to $90 \mathrm{~m}$ thick of predominantly olivine semiporphyritic bronzite basalts and more siliceous orthopyroxene-rich rocks. It is separated from unit 3 by picritic easily weathering flows. The lavas of unit 4 were erupted from a crater group in the Kûgánguaq valley, covering several square kilometres. Most remarkable is a bronzite basaltic ignimbritic unit with a lower $3 \mathrm{~m}$ thick glass palisade grading upwards into less-welded tuff. Within the complex a feeder dyke has been followed up into lava flows. The sequence has been mapped from Kûgánguaq $14 \mathrm{~km}$ towards the south-east.

Unit 5 comprises a series of aphyric basalts, olivine-poor basalts and feldsparphyric basalts. It is missing along the Vaigat in the western part of the section, but occurs 5-7 km inland. From the north-west towards the south-east the thickness increases and is more than $80 \mathrm{~m}$ at Qordlortorssuaq, where unit 5 is found in transition from subaerial to subaqueous facies. Columnar jointing is often extremely well developed within the unit. At Qordlortorssuaq a composite lava of nearly aphyric basalt and highly olivine-cumulative basalt rich in olivines up to $2.5 \mathrm{~cm}$ in length indicates that unit 5 represents olivine basalt magma that has fractionated under low pressure.

Unit 6. A period of weak volcanic activity followed during which erosion and 


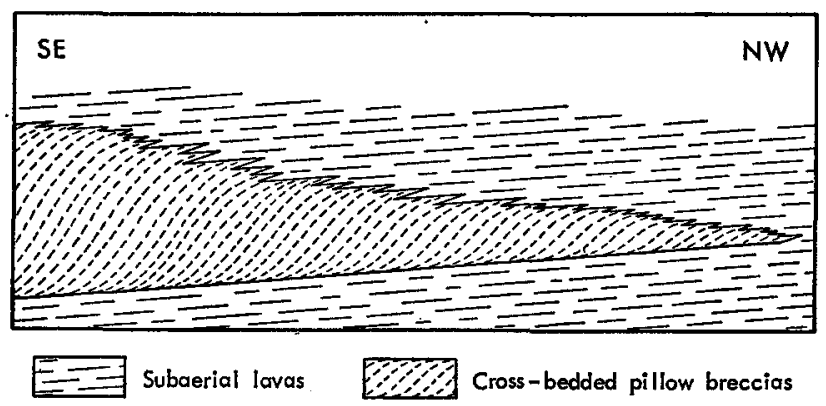

Fig. 9. Schematic diagram showing how subaerial lavas develop into subaqueous pillow breccias along the north coast of Disko.

formation of thin laterite-rich basalt conglomerates occurred towards the west. Deposition of up to $15 \mathrm{~m}$ of black shales with tuffs and plant fossils began around Qordlortorssuaq in the eastern part of the section. Among the plant fossils, the genus Macclintockia has been recognized. During this period, the sea transgressed more than $20 \mathrm{~km}$ towards the north-west.

Renewed intense volcanic activity characterized by small picritic eruptions followed. With indication of general provenance of magma from the north-west, the shoreline migrated gradually south-east, while picritic lavas flowed into the sea and filled the basin. One or more often fairly steeply dipping picrite basaltic pillow breccia beds record the single eruptions (fig. 9). As the shoreline moved towards the east, the lavas flowed into still deeper water, exceeding $250 \mathrm{~m}$ in the eastern part of the section. At one locality at Qordlortorssuaq the black shales resting on unit 5 were incorporated in the breccia and vertical flakes of slightly baked shale, up to $30 \mathrm{~m}$ long and a few metres thick can be seen in the pillow breccia.

Unit 7 is a sequence up to $50-60 \mathrm{~m}$ thick of dark brownish weathering mildly alkaline basalts. Up to 30 tongues and flows can build the sequence. The unit has been mapped over a distance of $20 \mathrm{~km}$ along the coast from $3 \mathrm{~km}$ east of Kûgánguaq to Asûtâ mountain, where the sequence develops into pillow breccias. The rocks show a varying content of olivine and grade into picritic types.

Above unit 7 the lower lava formation consists of easily weathering picrite basalts, which are normally less than $5 \mathrm{~m}$ thick. Massive erosion-resistant, olivinerich basalts occur in addition and form local marker horizons. The sequence develops into aqueous facies from Asûtâ to Qutdligssat, especially rapidly just west of the town.

\section{Upper lava formation}

Within the section about $800-900 \mathrm{~m}$ of the upper lava formation is exposed. Unit 8. The sinking of the plateau continued. In the eastern part of the section, 
from Qutdligssat to Qordlortorssuaq, a sequence of voluminous feldspar-phyric basalts can be seen to have filled out a newly formed basin. These lavas are extremely massive showing a perfect colonnade and a thick entablature. Their top layer seems to grade up into breccia. Towards the deeper part of the depression towards the south-east an increasing amount of breccia can be seen. Just south-east of Qutdligssat cross-bedded breccia has been observed showing provenance from the south-east. These lavas may have accumulated as shallow lava lakes and may thus owe their thickness to the topography. They may be the northern part of a trough characterized by feldspar-phyric basalt breccias extending through the south-eastern part of Kûgánguaq valley to south Disko around Godhavn, described here by Giesecke (1823), Rink (1853) and many others.

These feldspar-phyric basalts were covered by subaerial feldspar-phyric basaltic lavas and no further transgressions have been recorded from the lava sequence.

A transition zone between the lava formations includes feldspar-phyric basalts and strongly olivine-porphyritic flows. Some flows contain a number of cognate gabbroic inclusions indicating low-pressure fractionation. Upwards in the pile plagioclase-glomeroporphyritic basalts become predominant.

Unit 9. A sequence more than $100 \mathrm{~m}$ thick of phenocryst-poor basalts occurs above the plagioclase-porphyritic basalts, about $600-700 \mathrm{~m}$ above the base of the upper lava formation. Unit 9 covers the tops of the highest mountains in the area. At the base of unit 9 a sediment-contaminated plagioclase-porphyritic basalt is found, containing pyrometamorphosed sediment xenoliths and norite inclusions.

\section{Dykes}

A number of dykes striking NW-SE cut through the section. The dykes include olivine basalts, picrite basalts and feldspar-phyric basalts.

Special mention should be made of a strongly sediment-contaminated dyke discovered in Manîdtlat kugssinerssuat. It strikes NW-SE and could be traced at least $11 \mathrm{~km}$ towards the south-east to the mountain Pyramiden. The dyke is $4 \mathrm{~m}$ thick, is composite and includes an early pulse of olivine- and plagioclase-porphyritic basalt containing partially melted sediment inclusions and telluric iron. A baked sediment breccia was intruded together with the first pulse of magma and is found more than $700 \mathrm{~m}$ above the base of the volcanic sequence. A later pulse of magma was a strongly contaminated more siliceous and orthopyroxene-rich melt containing graphite, telluric iron and xenoliths of sediments, which have reacted with the magma and have been pyrometamorphosed.

Finally the discovery of several dykes containing gabbro xenoliths from northwest Disko around Jens Vahls Dal should be reported. 
The gabbros consist of plagioclase, clinopyroxene, olivine and ores and include distinct plagioclase cumulates, demonstrating the existence of a layered gabbro intrusion in this area below the present level of erosion.

\section{Age and correlation of the Disko lava plateau}

The black shales with plant fossils and tuffs from unit 6 may tentatively be correlated with bituminous shales from the lower part of the Naujat Member of the Upper Atanikerdluk Formation, described by Koch $(1959,1964)$ and correlated with the Upper Danian Agatdal Formation (Rosenkrantz in Koch, 1959).

If the correlation is correct an age of Upper Danian or older is indicated for about $1 \mathrm{~km}$ of basalts, mainly olivine basalts and picrite basalts from the lower lava formation.

The main transgression of the lava plateau of unit 6 may similarly be correlated with the Naujat Member transgression. The occurrence of Aussivik Member shales on top of the pillow breccias at Qutdligssat has been mentioned by Koch (1964). Therefore a correlation of a considerable part of the Disko lava plateau with the Upper Atanikerdluk Formation, at least from the Naujat Member and upwards is proposed.

\section{References}

Giesecke, C. L. 1823: On the mineralogy of Disko Island. Trans. R. Soc. Edinb. 9, 263-272. Henderson, G. (in press): The geological setting of the west Greenland basin in the Baffin Bay region. Pap. geol. Surv. Can. 71-23.

Koch, B. E. 1959: Contribution to the stratigraphy of the nonmarine Tertiary deposits on the south coast of Nûgssuaq peninsula, northwest Greenland with remarks on the fossil flora. Meddr Grønland 162, 1, $100 \mathrm{pp}$.

Koch, B. E. 1964: Review of fossil floras and nonmarine deposits of West Greenland. Bull. geol. Soc. Amer. 75, 535-548.

Pedersen, A. K. 1969: Preliminary notes on the Tertiary volcanic lavas of northern Disko. Rapp. Grønlands geol. Unders. 19, 21-24.

Pedersen, A. K. 1970: En petrologisk undersøgelse af tertiære vulkanske bjergarter fra det nordlige Disko. Unpublished thesis, Copenhagen University.

Rink, H. 1853: Udsigt over Nordgrönlands Geognosi, især med hensyn til Bjergmassernes mineralogiske Sammensætning. K. danske Vidensk. Selsk. Skr. 5 Række Naturv. math. Afd. 3, 71-98.

Steenstrup, K. J. V. 1882: Om Forekomsten af Nikkeljern med Widmannstättenske Figurer i Basalten i Nord-Grønland. Meddr Grønland 4, 113-132. 